aware of the dangers; and through accident or deliberate exposure in testing a theory, many suffered and some died. Among the less well-known stories is that of typhus fever, the terrible disease of besieging armies, beleaguered cities, filthy camps and prisons, carried by body lice. The name of the infective organism, Rickettsia prowazeki, was conferred by Rocha-Lima, a Brazilian who contracted typhus and became very ill; both of the scientists who are celebrated in the name, an American and an Austrian, died.

The insect vector appeared at first to be an easy target for the control of disease, and there were some notable early successes such as the campaigns against yellow fever and malaria in Cuba and Panama. But the detection and elimination of breeding sites was expensive and neverending, and the available agricultural pesticides were toxic or too irritant for human use. The discovery of new, potent, synthetic compounds was full of promise.

Busvine, at the London School of Hygiene and Tropical Medicine, has been working with the application of these compounds for most of his life. As long ago as 1940 he was testing the efficacy of new substances as delousing agents by spraying them on the underpants of London vagrants, and soon afterwards was impregnating shirts with the new Swiss insecticide DDT for British soldiers serving overseas (a measure that saved thousands of lives). He describes the worldwide impact of DDT and deals systematically with methods for controlling mosquitoes, midges, flies, ticks, mites, bugs, lice and fleas. DDT and other chlorinated hydrocarbons eventually became ineffective through misuse and the development of resistance, and new substances with different modes of action (anticholinesterases and synthetic pyrethroids) superseded them. These are more expensive than DDT and insects develop resistance to them also. The old methods - environmental control, traps, repellents and nets - are back in fashion, and some new biological and genetic control techniques are on trial. Future success depends on international training, cooperation and finance.

Busvine's style is easy and conversational, and he presents a wealth of specialized knowledge and personal experience to the general reader. With the excuse that this is not a book of reference, there is a list of contents but no index - which is a pity because there is plenty worth referring to. The illustrations are rather grey and flat, and there are some irritating misprints - perhaps because printing was done in faraway Bangalore.

Len Goodwin, formerly with the Wellcome Trust, is at Shepperlands Farm, Park Lane, Finchampstead, Wokingham, Berkshire RG11 4QF, UK.

\section{Seeds of Gaia}

\section{Bill Chaloner}

Faith in a Seed: The Dispersion of Seeds and Other Late Natural History Writings by Henry Thoreau. Edited by B. P. Dean. Island: 1993. Pp. 283. \$25.

WHEN Henry David Thoreau's aunt asked him on his deathbed whether he had made peace with his god, he replied that he did not know that they had quarrelled. It is disappointing to find that a man who can come up with such impromptu wit in extremis can write such uninspired ramblings when he is in a more relaxed frame of mind.

Thoreau died at the age of 44, apparently from tuberculosis aggravated by a cold caught while walking in the rain in his

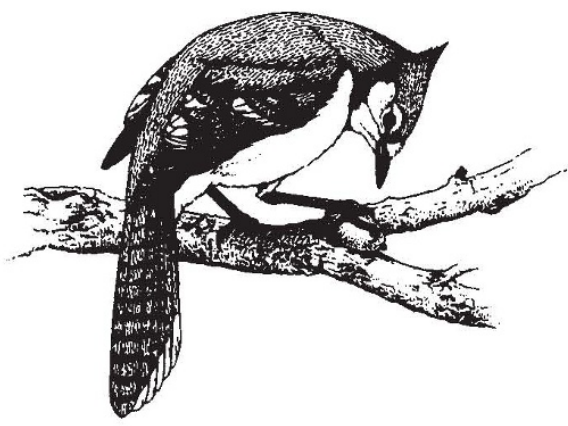

beloved Massachusetts woods. He is probably best known for Walden, written while living in a hut on the edge of a lake outside Boston in the years 1845-47, in which he expounded his rugged New England philosophy and agri-ecological contemplation. Thoreau is noteworthy for his meticulous observation of plant and animal life in last-century New England, and seeing in its workings a moral message for humankind. After the appearance of $\mathrm{Wal}$ den in 1854 he published little more, but continued to make voluminous notes on the biology of the woodlands near his home in Concord. These were intended to lead to a book on the dispersion of seeds, which he left unfinished. Research into these notes became the subject of a $\mathrm{PhD}$ dissertation at the University of Connecticut, by the editor of this posthumous work, Bradley P. Dean. His edited version of Thoreau's notes, and those for three other small unpublished naturalhistory works of Thoreau, form the basis of this book. Beyond Thoreau's text, there is the delightful addition of Abigail Rorer's beguiling little marginal drawings, as shown here. These are not only a delight in themselves, but give a pleasingly nineteenth-century touch to the page layout, as the lines are tailored to wander around a red-oak seedling or the skeleton of a deer-mouse.

In his foreword, Gary Nabhan tells us with disconcerting honesty that Odell Shepherd, editor of the Heart of Thoreau's Journals, considered Thoreau's observations on seed biology "a chapter of his lifework best left unpublished". Readers must judge for themselves, but I think it is at least fair to say that those who look here for new scientific insights into the reproductive biology of plants will be disappointed. The work is of value more for what it tells us about Thoreau than about the plant life of Massachusetts.

Thoreau's somewhat anecdotal style is reminiscent of Gilbert White's The Natural History of Selborne, rather than that of his contemporary Charles Darwin. The comparison is of interest, since Thoreau read and wrote notes on The Origin of Species in 1860 , while writing his seed book. He was at that time also acting as a collector for Louis Agassiz, king of Harvard biology and arch-opponent of Darwinism. Indeed, Thoreau was invited to sit on a Harvard committee charged with an annual evaluation of its Natural History syllabus - plus ça change! Since Thoreau was evidently an exponent of evolution by natural selection, the minutes of those meetings would make interesting reading.

Thoreau seems to have been an early victim of the conflict between the Two Cultures. He wrote in 1851: "what sort of science is that which enriches the understanding but robs the imagination?" $\mathrm{He}$ need not have worried; Gary Nabhan believes that "the loveliest passages in his treatise on seeds are those in which his deep reservoir of literary knowledge wells up into his science". That is a fair comment, and one that would surely have pleased Thoreau.

The title of this compilation is not merely apt but descriptive of its contents; like many expositions of faith, it can be read at different levels. For Thoreau, seeds are a symbol not only of the dissemination of life and its capacity for regeneration, but perhaps even of resurrection. He suggests, optimistically, that "it is remarkable how Nature endeavours to keep the earth clothed with wood of some kind". (There writes a New Englander; the inhabitants of Arizona or Alaska might see Nature's endeavours in other terms ....) But his faith in Nature goes further: "the very earth itself is a granary and a seminary . . . so that to some minds its surface is regarded as the cuticle of one living creature". In the ubiquity and fecundity of seeds, Thoreau seems to have found intimations of Gaia a good century before Lovelock.

Bill Chaloner is in the Department of Biolo gy, Royal Holloway, University of London, Egham Hill, Egham, Surrey TW20 OEX, UK. 